\title{
Growing Evidence about the Relationship between Vessel Dissection and Scuba Diving
}

\author{
Simona Brajkovic ${ }^{a} \quad$ Giulietta Riboldi $^{\mathrm{a}} \quad$ Alessandra Govoni ${ }^{\mathrm{a}}$ \\ Stefania Corti ${ }^{a} \quad$ Nereo Bresolin ${ }^{a, b}$ Giacomo Pietro Comi ${ }^{a}$ \\ ${ }^{a}$ Dino Ferrari Centre, Neuroscience Section, Department of Pathophysiology and \\ Transplantation, University of Milan, Neurology Unit, IRCCS Foundation Ca' Granda \\ Ospedale Maggiore Policlinico, Milan, and ${ }^{b}$ IRCCS Eugenio Medea, Bosisio Parini, \\ Lecco, Italy
}

\section{Key Words}

Internal carotid dissection · Scuba diving $\cdot$ Claude Bernard-Horner syndrome $\cdot$ XII cranial nerve

\begin{abstract}
Carotid and vertebral artery dissection are relatively frequent and risky conditions. In the last decade, different patients with extracranial (and in 1 case also intracranial) dissections associated with the practice of scuba diving were reported. The connection between the two conditions has not been fully explained so far. In the present article, we report the case of a patient presenting with Claude Bernard-Horner syndrome and homolateral XII cranial nerve palsy, manifesting a few days after diving in the cold water of a lake. The patient ended up having internal carotid artery dissection associated with the formation of a pseudoaneurysm. Here, we offer a summary of all cases reported in the literature about scuba diving and arterial dissection, and provide a critical discussion about which scuba diving-related factors can trigger the dissection of cervical vessels.

(c) 2013 S. Karger AG, Basel
\end{abstract}

\section{Introduction}

Dissection of cervical vessels is generally uncommon in the population, but unfortunately, it is a relatively frequent cause of stroke in young patients [1]. In recent years, an interesting correlation was noticed between scuba diving and the dissection of the major arteries of the neck, promoting the identification of this sport as a possible risk factor [2-10].

Prof. Giacomo P. Comi

Department of Neurological Sciences, University of Milan

IRCCS Foundation Ca' Granda Policlinico, Via Francesco Sforza 35

IT-20122 Milan (Italy)

E-Mail giacomo.comi@unimi.it 
Brajkovic et al:: Growing Evidence about the Relationship between Vessel Dissection and Scuba Diving

Our article describes the case of a 52-year-old man who, after diving into a lake, experienced a dissection of the internal carotid artery (ICA) complicated by a pseudoaneurysm. In addition, we offer a summary of the few cases reported so far, giving a critical overview in the attempt to recognize which conditions could contribute to this complication.

\section{Case Report}

A 52-year-old-man presented with headache and homolateral Horner's syndrome which had started 4 weeks previously.

On the day after scuba diving in cold water, the patient complained of a considerable and persistent neck pain which irradiated towards the left retroocular region. On the following morning, a left-sided facial edema appeared and lasted for a few days. The persistence of the headache, ptosis and miosis, which increased with the worsening of the neck pain, led the patient to seek a neurological evaluation. The examination revealed only the presence of an incomplete Claude Bernard-Horner syndrome (CBHS). Ultrasonography (US) of the carotid arteries did not show plaques or stenosis of the vessels. The fluid dynamic and velocity were normal. A chest X-ray was performed and revealed the presence of a thickening of the right pulmonary apex and several little nodules in the homolateral superior lobe, which were firstly attributed by the radiologist to an expression of a possible old lesion.

The patient's past medical history was characterized by benign arterial hypertension treated with Enalapril (20 mg/day), benign prostatic hypertrophy, tension headache attacks and bronchopneumonia at a young age. In his family, his father had died due to pulmonary cancer; his mother and his younger brother were in good health. He had a 19-year-old son with no medical problems.

Four weeks after the beginning of the symptoms, the patient was admitted to our department. The neurological examination showed a left Horner's syndrome, with normal direct and consensual response to the light stimulus, and no signs of either fatigability or diplopia in any direction of gaze (fig. 1a). He also presented with a dysesthesic area in the left side of the head, particularly in the parietal and frontal regions, without a clear distribution in the territory of the $\mathrm{V}$ cranial nerve innervation. A left-sided deviation of the tongue, when protruded, was also detected (fig. 1b). No other neurological alterations were found. Head and neck pain had disappeared.

A head CT scan was performed, but no abnormalities were detected. Because of the persistence of an incomplete CBHS and the family history of lung cancer, in order to exclude the presence of malignancy, we discussed the chest X-ray findings with a lung specialist, who confirmed the hypothesis that the right lobe nodules were scars of a previous disease. Since these lesions were also contralateral to the CBHS, no further investigations were carried out during hospitalization. A follow-up was recommended.

The ophthalmologic evaluation showed only a slight increase of the left eye tone and confirmed the presence of anisocoria with miosis in the left eye.

Despite the normal US findings, we performed brain and vascular magnetic resonance imaging (MRI), aiming at a better investigation of both intra- and extracerebral circulation and potential parenchymal ischemic lesions. The examination did not show any infarctions. Otherwise, MRI revealed a dissection of the ICA in the precarotid region associated with a pseudoaneurysmatic deformation (fig. 2a). An aneurysm at the bifurcation of the left middle cerebral artery was also found. Cardiac disease could be excluded by echocardiogram.

The patient was treated with anticoagulant therapy (Aspirin $100 \mathrm{mg}$ /day). In a followup brain and vessel MRI 1 month later (therefore, 2 months after the beginning of the 
Brajkovic et al:: Growing Evidence about the Relationship between Vessel Dissection and Scuba Diving

symptoms), a slight decrease of both the dissection and the pseudoaneurysmatic lesion of the left ICA could be detected (fig. 2b). Parenchymal lesions were never visible.

\section{Discussion}

In recent years, there were quite a few reports about the association between scuba diving and cerebral arterial dissection. The presenting symptoms differ among cases according to the territory of interest and the presence of central nervous system ischemic lesions. With the present work, we want to add another report to the list, in order to promote an in-depth analysis of the problem and, possibly, to define the associated risk factors that can be avoided by scuba divers to prevent this major complication. In the small database offered by the literature, we noticed that in most patients, a dissection of the carotid artery was reported, compared with vertebral vessels, consistent with the general frequency of these lesions [2-10].

None of the case reports mentioned significant head trauma or clinical conditions usually associated with spontaneous dissection, such as Marfan syndrome, Ehlers-Danlos syndrome and, in general, connective tissue diseases. Probably, other significant risk factors associated with immersion/emersion processes have a greater effect on the dissection than the classical ones. Hafner et al. [10], in a critical review of the literature about scuba diving and related vessel dissection, proposed that a causative factor may be the hyperextension of the neck during the process of immersion and emersion, probably added to the increasing pressure to which the body is exposed during the descent.

Diving duration, timing of ascent or depth were not related to a greater risk of dissection, thus other diving-related factors may be implicated [7, 8]. Some causes proposed to trigger vessel dissection in scuba divers are exaggerated cervical movements, especially neck hyperextension or rotation, also complicated by the necessity to bear the weight of diving gear, and the demanding physical exercise required during immersion/emersion. Other factors which may contribute to triggering cervical vessel dissection are the temperature of the water and the exposure to gas influencing the regulation of the vessel wall. For instance, a transient increase of $\mathrm{PaCO}_{2}$ can commonly occur in scuba divers for either intentional or unintentional hypoventilation or excessive physical exercise underwater, where the work of breathing increases, impairing gas exchange and facilitating carbon dioxide accumulation [11]. Furthermore, the immersion in extremely cold water can provoke trigeminal neuralgia, but also a tension headache which can be associated with a contraction of cervical muscles, which lack their flexibility, increasing the vulnerability of the neck structures [11]. It would be interesting to know in which season and in which place the patients described in previous reports performed scuba diving and if they experienced a period of hypoventilation. Probably, there is not a single scuba diving-related cause leading to a greater risk of artery dissection, but several factors work together to increase the susceptibility to such a complication.

Carotid dissection mostly presents with neck or head pain and signs of cerebral ischemic lesions. All cases previously reported presented with this clinical picture. The case we report was particularly misleading because of the presence of symptoms associated only with the mechanical compression of the pseudoaneurysm caused by the vessel dissection. Tongue deviation and homolateral Horner's syndrome could be associated with several causes. Rowley et al. [12] reported a patient developing these two signs caused by hypoglossal and trigeminal palsy in addition to Horner's syndrome after an epidural block. Other causes include carotid body tumors or clonus tumor, and side effects of the embolization 
therapy for carotid body tumors, atypical lesions such as a gunshot, sclerosing inflammatory pseudotumor and septic erosion [13-18]. In addition, the complete negativity of the US imaging performed in early stages made the diagnosis even more difficult. The sensitivity of the US was estimated to be between 92 and 96\% compared to MRI and MRI angiography $[19,20]$. It is also true that the greatest part of false negatives concern lesions in regions difficult to assess by US and the detection of intramural hematomas, as was the case in our patient.

To date, a discussion is ongoing about which therapy should be preferred for carotid artery dissection: anticoagulant or antiplatelet therapy [1]. However, American guidelines about the treatment of extracranial carotid dissection recommend the use of antithrombotic treatment with either a platelet inhibitor or an anticoagulant (Class of Evidence II, Level A) [21]. In our case, the patient presented also with an aneurysm in the middle cerebral artery that could have had a greater risk of bleeding with anticoagulant therapy. Therefore, we decided to start treating the patient with antiplatelet therapy.

We reviewed (table 1) the few cases of artery dissection described so far in the literature, including also the ones regarding unusual dissection location, which probably depends on the particular movements of the divers during the immersion/emersion phases. Thus, when a scuba diver is admitted to the emergency department complaining of neck or head pain and/or focal neurologic signs, an artery dissection should be suspected because recovery strictly depends on early initiation of therapy, and a late diagnosis may facilitate a progression of the disease, such as an extended infarction or a contralateral dissection [22].

\section{Acknowledgements}

We wish to thank the patient for his support and collaboration.

\section{Disclosure Statement}

The authors have no conflicts of interest to declare.

\section{References}

1 Patel RR, Adam R, Maldjian C, Lincoln CM, Yuen A, Arneja A: Cervical carotid artery dissection: current review of diagnosis and treatment. Cardiol Rev 2012;20:145-152.

-2 Nelson EE: Internal carotid artery dissection associated with scuba diving. Ann Emerg Med 1995;25:103106.

3 Mayer SA, Rubin BS, Starman BJ, Byers PH: Spontaneous multivessel cervical artery dissection in a patient with a substitution of alanine for glycine (G13A) in the alpha 1 (I) chain of type I collagen. Neurology 1996;47:552-556.

-4 Konno K, Kurita H, Ito N, Shiokawa Y, Saito I: Extracranial vertebral artery dissection caused by scuba diving. J Neurol 2001;248:816-817.

5 Gibbs JW 3rd, Piantadosi CA, Massey EW: Internal carotid artery dissection in stroke from SCUBA diving: a case report. Undersea Hyperb Med 2002;29:167-171.

6 Skurnik YD, Sthoeger Z: Carotid artery dissection after scuba diving. Isr Med Assoc J 2005;7:406-407.

7 Bartsch T, Palaschewski M, Thilo B, Koch AE, Stingele R, Volkmann J, et al: Internal carotid artery dissection and stroke after SCUBA diving: a case report and review of the literature. J Neurol 2009;256:1916-1919.

-8 Koçyiğit A, Cinar C, Kitiş O, Calli C, Oran I: Isolated PICA dissection: an unusual complication of scuba diving: case report and review of the literature. Clin Neuroradiol 2010;20:171-173.

\9 Kasravi N, Leung A, Silver I, Burneo JG: Dissection of the internal carotid artery causing Horner syndrome and palsy of cranial nerve XII. CMAJ 2010;182:E373-E377. 


\begin{tabular}{l|l}
\hline DOI: $10.1159 / 000354979$ & $\begin{array}{l}\text { C } 2013 \text { S. Karger AG, Basel } \\
\text { www.karger.com/crn }\end{array}$ \\
\hline
\end{tabular}

Brajkovic et al:: Growing Evidence about the Relationship between Vessel Dissection and Scuba Diving

10 Hafner F, Gary T, Harald F, Pilger E, Groell R, Brodmann M: Dissection of the internal carotid artery after SCUBA-diving: a case report and review of the literature. Neurologist 2011;17:79-82.

Cheshire WP: Headache and facial pain in scuba divers. Curr Pain Headache Rep 2004;8:315-320.

Rowley C, Onslow J, Weston A: Hypoglossal nerve palsy, trigeminal nerve palsy and Horner's syndrome in association with epidural block. Int J Obstet Anesth 2009;18:191-192.

13 Li-shan L, Chang-wei L, Heng G, Yue-hong Z, Xing-ming C, Yong-jun L: Efficacy of surgical therapy for carotid body tumors. Chin Med Sci J 2011;26:241-245.

14 Spector GJ, Gado M, Ciralsky R, Ogura JH, Maisel RH: Neurologic implications of glomus tumors in the head and neck. Laryngoscope 1975;85:1387-1395.

15 Wiegand S, Kureck I, Chapot R, Sesterhenn AM, Bien S, Werner JA: Early side effects after embolization of a carotid body tumor using Onyx. J Vasc Surg 2010;52:742-745.

-16 Hagemann G, Willig V, Fitzek C, Witte OW: Gunshot-induced artery dissection with twelfth nerve palsy. Arch Neurol 2003;60:280-281.

17 Okamoto M, Takahashi H, Yamanaka J, Nemoto S, Kuno K, Ishii T: Sclerosing inflammatory pseudotumor arising from the carotid artery region. Auris Nasus Larynx 1997;24:315-320.

$\checkmark 18$ Eneroth CM, Tham R: Pseudoaneurysm of the internal carotid artery. A warning of a septic erosion. Acta Otolaryngol 1971;72:445-450.

19 Nebelsieck J, Sengelhoff C, Nassenstein I, Maintz D, Kuhlenbäumer G, Nabavi DG, et al: Sensitivity of neurovascular ultrasound for the detection of spontaneous cervical artery dissection. J Clin Neurosci 2009;16:79-82.

20 Benninger DH, Georgiadis D, Gandjour J, Baumgartner RW: Accuracy of color duplex ultrasound diagnosis of spontaneous carotid dissection causing ischemia. Stroke 2006;37:377-381.

-21 American College of Cardiology Foundation/American Heart Association Task Force; American Stroke Association; American Association of Neuroscience Nurses; American Association of Neurological Surgeons; American College of Radiology; American Society of Neuroradiology; Congress of Neurological Surgeons; Society of Atherosclerosis Imaging and Prevention; Society for Cardiovascular Angiography and Interventions; Society of Interventional Radiology; Society of Neurointerventional Surgery; Society for Vascular Medicine; Society for Vascular Surgery; American Academy of Neurology; Society of Cardiovascular Computed Tomography; Brott TG, Halperin JL, Abbara S, Bacharach JM, Barr JD, Bush RL, Cates CU, Creager MA, Fowler SB, Friday G, Hertzberg VS, McIff EB, Moore WS, Panagos PD, Riles TS, Rosenwasser RH, Taylor AJ: 2011 ASA/ACCF/AHA/AANN/AANS/ACR/ASNR/CNS/SAIP/SCAI/SIR/SNIS/SVM/SVS guideline on the management of patients with extracranial carotid and vertebral artery disease: executive summary. J Neurointerv Surg 2011;3:100-130, erratum in J Neurointerv Surg 2011;3:245.

22 Dziewas R, Konrad C, Dräger B, Evers S, Besselmann M, Lüdemann P, et al: Cervical artery dissection clinical features, risk factors, therapy and outcome in 126 patients. J Neurol 2003;250:1179-1184. 
Table 1. Comparison of the main features of the cases describing a vessel dissection associated with scuba diving

\begin{tabular}{|c|c|c|c|c|c|c|c|c|}
\hline $\begin{array}{l}\text { Refe- } \\
\text { rences }\end{array}$ & $\begin{array}{l}\text { Age/ } \\
\text { sex }\end{array}$ & Clinical features & Dissected vessel & $\begin{array}{l}\text { Associated } \\
\text { stroke }\end{array}$ & $\begin{array}{l}\text { Connective } \\
\text { tissue } \\
\text { disease }\end{array}$ & $\begin{array}{l}\text { Vascular risk } \\
\text { factors }\end{array}$ & Therapy & Recovery \\
\hline $\begin{array}{l}\text { Nelson, } \\
1995[2]\end{array}$ & $\begin{array}{l}52 / \\
M\end{array}$ & $\begin{array}{l}\text { frontal headache, expressive } \\
\text { aphasia followed by visual } \\
\text { disturbances, confusion and } \\
\text { right hemisoma paresis }\end{array}$ & $\begin{array}{l}\text { left ICA dissection } \\
\text { progressing to a } \\
\text { bilateral ICA } \\
\text { dissection }\end{array}$ & $\begin{array}{l}\text { left parietal and } \\
\text { anterior cerebral } \\
\text { infarcts }\end{array}$ & - & - & $\begin{array}{l}\text { anticoagulant } \\
\text { therapy } \\
\text { (warfarin) for } 3 \\
\text { months after } \\
\text { hospital } \\
\text { discharge }\end{array}$ & $\begin{array}{l}\text { mild } \\
\text { expressive } \\
\text { aphasia, } \\
\text { unsteady gait } \\
\text { and a } \\
\text { complete } \\
\text { recovery of } \\
\text { upper limb } \\
\text { function }\end{array}$ \\
\hline $\begin{array}{l}\text { Mayer } \\
\text { et al., } \\
1996[3]\end{array}$ & $\begin{array}{l}35 / \\
\mathrm{F}\end{array}$ & $\begin{array}{l}\text { neck pain followed by bilateral } \\
\text { frontal and occipital headache, } \\
\text { vertigo, nausea and vomiting, } \\
\text { nystagmus in all directions of } \\
\text { gaze, mild right facial weakness } \\
\text { and ataxia; severe dysphagia and } \\
\text { respiratory failure; right } \\
\text { Horner's syndrome progressing } \\
\text { to bilateral brainstem deficits }\end{array}$ & $\begin{array}{l}\text { bilateral vertebral } \\
\text { artery }(\mathrm{C} 2 \text { level) and } \\
\text { ICA dissection }\end{array}$ & $\begin{array}{l}\text { left superior } \\
\text { cerebellum and } \\
\text { right postero- } \\
\text { lateral medulla } \\
\text { infarctions }\end{array}$ & $\begin{array}{l}\text { osteogenesis } \\
\text { imperfecta } \\
\text { (point } \\
\text { mutation in } \\
\text { COL1A1 } \\
\text { gene) }\end{array}$ & - & $\begin{array}{l}\text { long-term } \\
\text { anticoagulant } \\
\text { therapy (firstly } \\
\text { intravenous, } \\
\text { then orally) }\end{array}$ & $\begin{array}{l}\text { complete } \\
\text { recovery of the } \\
\text { neurologic } \\
\text { impairment }\end{array}$ \\
\hline $\begin{array}{l}\text { Konno } \\
\text { et al., } \\
2001[4]\end{array}$ & $\begin{array}{l}18 / \\
M\end{array}$ & $\begin{array}{l}\text { right occipital headache and } \\
\text { neck pain progressing to vertigo } \\
\text { and left upper quadrant } \\
\text { hemianopsia }\end{array}$ & $\begin{array}{l}\text { right cervical } \\
\text { vertebral artery } \\
\text { dissection }\end{array}$ & $\begin{array}{l}\text { right cerebellar } \\
\text { hemispheric and } \\
\text { medial occipital } \\
\text { infarctions }\end{array}$ & - & - & $\begin{array}{l}\text { anticoagulant } \\
\text { therapy } \\
\text { (warfarin) for } 1 \\
\text { month, aspirin } \\
\text { subsequently }\end{array}$ & - \\
\hline $\begin{array}{l}\text { Gibbs } \\
\text { et al., } \\
2002[5]\end{array}$ & $\begin{array}{l}38 / \\
F\end{array}$ & $\begin{array}{l}\text { confusion, headache, nausea, } \\
\text { vomiting, dysphasia and left } \\
\text { hemisoma paresis }\end{array}$ & right ICA dissection & $\begin{array}{l}\text { right } \\
\text { corticoparietal } \\
\text { infarct }\end{array}$ & - & - & $\begin{array}{l}\text { anticoagulant } \\
\text { therapy (firstly } \\
\text { intravenous, } \\
\text { then orally for } 6 \\
\text { months) }\end{array}$ & $\begin{array}{l}\text { complete } \\
\text { recovery at } \\
6 \text {-month } \\
\text { follow-up }\end{array}$ \\
\hline $\begin{array}{l}\text { Skurnik } \\
\text { et al., } \\
2005[6]\end{array}$ & $\begin{array}{l}48 / \\
M\end{array}$ & $\begin{array}{l}\text { neck and face pain, taste } \\
\text { alterations, complete Horner's } \\
\text { syndrome }\end{array}$ & $\begin{array}{l}\text { distal extracranial left } \\
\text { ICA dissection }\end{array}$ & - & - & - & $\begin{array}{l}\text { anticoagulant } \\
\text { therapy (firstly } \\
\text { intravenous, } \\
\text { then orally for } 6 \\
\text { months) }\end{array}$ & $\begin{array}{l}\text { complete } \\
\text { recovery at } \\
3 \text {-month } \\
\text { follow-up }\end{array}$ \\
\hline $\begin{array}{l}\text { Bartsch } \\
\text { et al., } \\
2009[7]\end{array}$ & $\begin{array}{l}51 / \\
M\end{array}$ & $\begin{array}{l}\text { expressive aphasia, dysphagia, } \\
\text { aching throat, left-sided } \\
\text { temporal-occipital headache, } \\
\text { incomplete Horner's syndrome, } \\
\text { dysarthria, left-sided tongue } \\
\text { deviation and uvula deviation }\end{array}$ & $\begin{array}{l}\text { left extracranial ICA } \\
\text { dissection causing an } \\
\text { intramural hematoma } \\
\text { which led to a local } \\
\text { pressure palsy of IX } \\
\text { and XII cranial nerves }\end{array}$ & $\begin{array}{l}\text { left } \\
\text { corticoparietal } \\
\text { embolic infarcts }\end{array}$ & - & $\begin{array}{l}\text { smoking (20 } \\
\text { cigarettes/day } \\
\text { until 1990) }\end{array}$ & $\begin{array}{l}\text { anticoagulant } \\
\text { therapy (firstly } \\
\text { intravenous, } \\
\text { then orally) }\end{array}$ & $\begin{array}{l}\text { complete } \\
\text { regression of } \\
\text { neurologic } \\
\text { deficits }\end{array}$ \\
\hline $\begin{array}{l}\text { Koçyiğit } \\
\text { et al., } \\
2010[8]\end{array}$ & $\begin{array}{l}32 / \\
M\end{array}$ & drowsiness & $\begin{array}{l}\text { isolated dissection at } \\
\text { the posterior } \\
\text { medullary segment of } \\
\text { the left } \\
\text { posteroinferior } \\
\text { cerebellar artery }\end{array}$ & $\begin{array}{l}\text { acute ischemia of } \\
\text { the left } \\
\text { posteroinferior } \\
\text { cerebellar artery } \\
\text { territory }\end{array}$ & - & - & $\begin{array}{l}\text { antiplatelet } \\
\text { therapy } \\
\text { (aspirin) }\end{array}$ & $\begin{array}{l}\text { complete } \\
\text { recovery }\end{array}$ \\
\hline $\begin{array}{l}\text { Kasravi } \\
\text { et al., } \\
2010 \text { [9] }\end{array}$ & $\begin{array}{l}61 / \\
M\end{array}$ & $\begin{array}{l}\text { left-sided headache, incomplete } \\
\text { Horner's syndrome, dysarthria, } \\
\text { dysphagia and left-sided tongue } \\
\text { deviation }\end{array}$ & $\begin{array}{l}\text { dissection of the distal } \\
\text { extracranial and } \\
\text { petrous segment of } \\
\text { the left ICA and } \\
\text { associated mural } \\
\text { hematoma }\end{array}$ & - & - & - & $\begin{array}{l}\text { antiplatelet } \\
\text { therapy } \\
\text { (aspirin) }\end{array}$ & $\begin{array}{l}\text { an almost } \\
\text { complete } \\
\text { recovery after } \\
6 \text { months }\end{array}$ \\
\hline $\begin{array}{l}\text { Hafner } \\
\text { et al., } \\
2011[10]\end{array}$ & $\begin{array}{l}37 / \\
\mathrm{F}\end{array}$ & $\begin{array}{l}\text { left-sided facial paresthesias and } \\
\text { left-cervical pain, left ear's } \\
\text { pressure feeling and tinnitus }\end{array}$ & left ICA dissection & - & - & $\begin{array}{l}\text { nicotine abuse } \\
(15 \text { pack- } \\
\text { years })\end{array}$ & $\begin{array}{l}\text { oral } \\
\text { anticoagulant } \\
\text { therapy for } 3 \\
\text { months }\end{array}$ & $\begin{array}{l}\text { complete } \\
\text { recovery at } \\
3 \text {-month } \\
\text { follow-up }\end{array}$ \\
\hline $\begin{array}{l}\text { Present } \\
\text { study }\end{array}$ & $\begin{array}{l}52 / \\
M\end{array}$ & $\begin{array}{l}\text { neck pain with an anterior } \\
\text { irradiation towards the left } \\
\text { retroocular region, left facial } \\
\text { edema and dysesthesia, Horner's } \\
\text { syndrome, left-sided tongue } \\
\text { deviation }\end{array}$ & $\begin{array}{l}\text { left ICA dissection in } \\
\text { the precarotid region } \\
\text { associated with an } \\
\text { intramural dilatation, } \\
\text { aneurysmatic lesion at } \\
\text { the bifurcation of the } \\
\text { left middle cerebral } \\
\text { artery }\end{array}$ & - & - & $\begin{array}{l}\text { arterial } \\
\text { hypertension }\end{array}$ & $\begin{array}{l}\text { antiplatelet } \\
\text { therapy } \\
\text { (aspirin) }\end{array}$ & $\begin{array}{l}\text { regression of } \\
\text { the symptoms } \\
\text { caused by } \\
\text { hypoglossal } \\
\text { nerve palsy, a } \\
\text { mild improve- } \\
\text { ment of the } \\
\text { other signs }\end{array}$ \\
\hline
\end{tabular}

Brajkovic et al.: Growing Evidence about the Relationship between Vessel Dissection and Scuba Diving

C 2013 S. Karger AG, Base

www.karger.com/crn 
Brajkovic et al:: Growing Evidence about the Relationship between Vessel Dissection and Scuba Diving
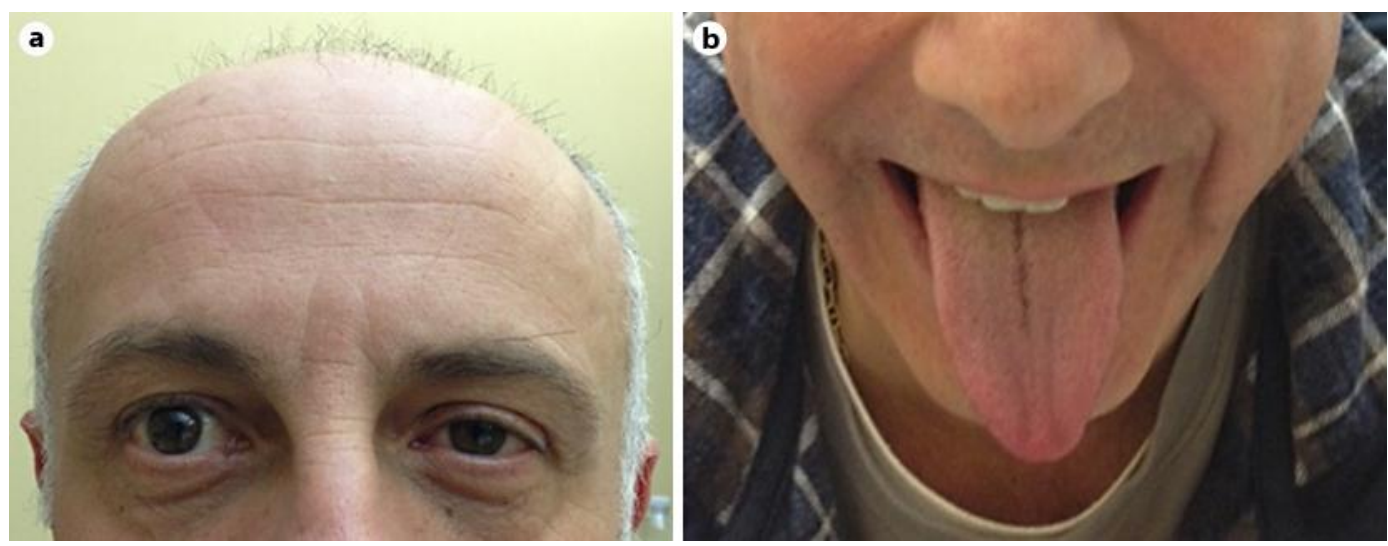

Fig. 1. Picture of the patient at the end of hospitalization. a Ptosis and miosis of the left eye. b A slight leftsided deviation of the tongue when protruded out of the mouth.
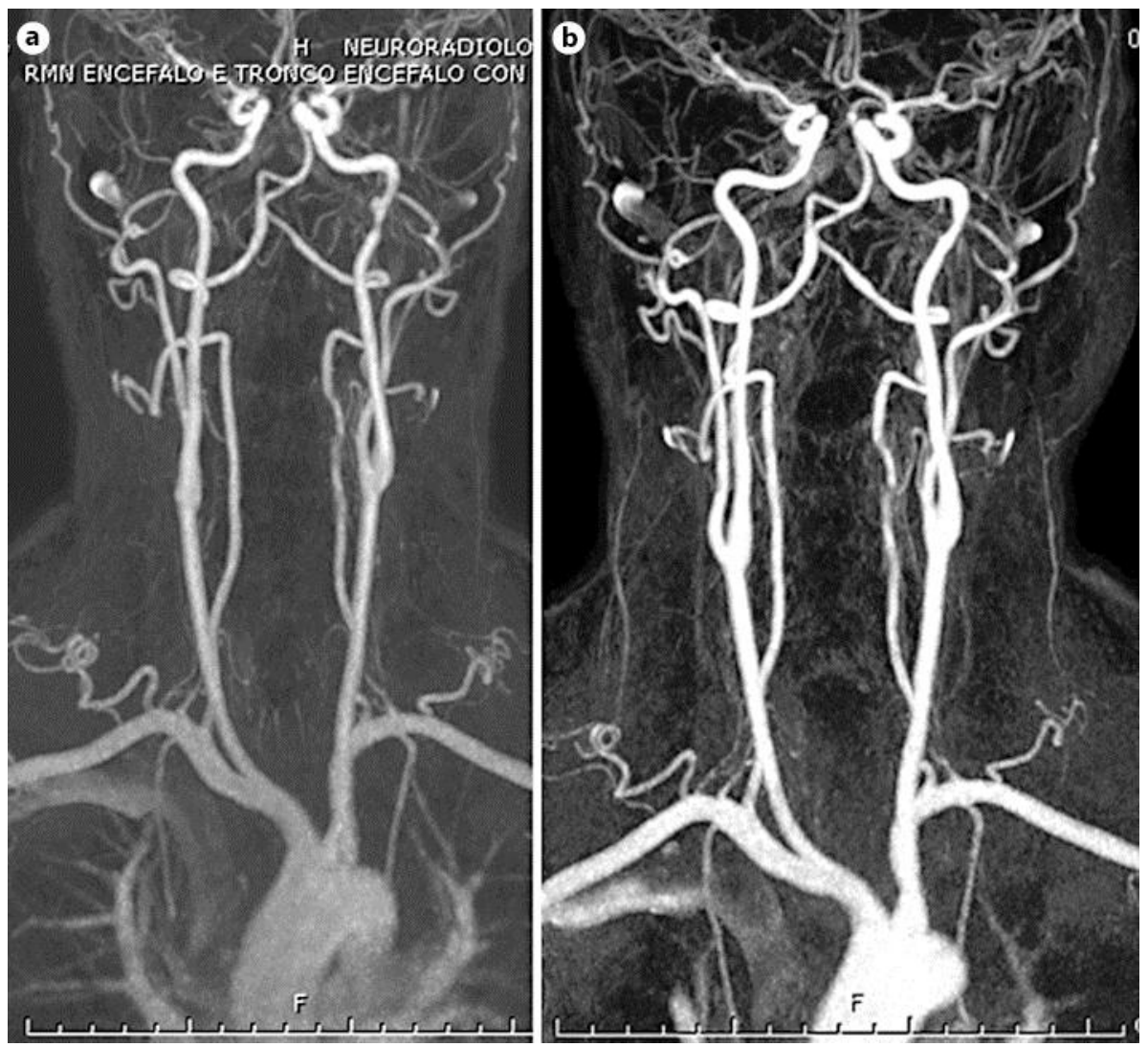

Fig. 2. Vascular MRI studies of the patient. a Vascular MRI performed at the beginning of the hospitalization: it clearly shows the dissection with the pseudoaneurysm of the left internal carotid vessel. $\mathbf{b}$ Vascular MRI performed 2 months after onset of the symptoms: the lesion of the left ICA has decreased significantly. 